\title{
Exchange and Investment Approach as a Framework for Analysis of the Organizational Commitment of Teachers of Privates Schools of Morang, Nepal
}

\author{
Arjun Rai ${ }^{1}$, Chandra Kumar Rai ${ }^{2}$ \\ ${ }^{1}$ Principal Author \\ Lecturer
}

Faculty of Management, Mahendra Multiple Campus, Dharan, Tribhuvan University, Nepal

${ }^{2}$ Corresponding author

Associate Professor

Faculty of Management, Mahendra Multiple Campus, Dharan, Tribhuvan University, Nepal

Email: ${ }^{1}$ arjun.rai@mahmc.tu.edu.np ${ }^{2}$ chandra.rai@mahmc.tu.edu.np

DOI: https://doi.org/10.3126/dristikon.v10i1.34538

\begin{abstract}
This study investigates the effect of monthly pay, the number of dependents of the teachers, age, and tenure year on the organizational commitment of the teachers working in the private schools of Morang. The population in this study includes all teachers working in the private schools of Morang district. This study used a pre-tested instrument to collect the data. This study employed Multiple regression analysis as an analytical tool to test the hypothesis of the research. Statistical Package for Social Science (SPSS), version 25, was used for the data analysis. The findings of the study- monthly pay, the number of dependents in the family of the teachers, and age had a significant positive impact on the organizational commitment of the teachers, but and tenure year had a significant negative effect on the organizational commitment. The originality of this study: this study shows (1) the effects of monthly payments, the number of people dependent on the job holder, age, and tenure period on the organizational commitment in the Nepalese setting. (2) Location and the population of the study are unique (no previous researches were conducted to examine the relations between the dependent and independent variables used in this study; the target population of the study- the teachers working in the private schools in Morang.
\end{abstract}

Keywords: organizational commitment, age, tenure period, pay, dependents, investment approach, exchange approach

\section{Introduction}

\section{Background of the Study}

Many human resource managers use the concept of organizational commitment of employees as a predictor of employee retention (Idris, 2014). The organizational commitment 
was identified as significant predictors of employee retention (Allen \& Meyer, 1996; Meyer \& Allen, 1997; Mowday et al., 1979; Mowday et al., 1982; Suliman \& Ilies, 2000; Tuna et al., 2016). Employee turnover seriously impedes the ability of an organization to deliver its promised products and services consistently. Employee turnover is a significant concern for many organizations nowadays, and has a devastating effect on an organization, especially if the lost employees are high performers (Wu \& Polsaram, 2011; Hassan, 2014).

To curb the turnover of the employees, the managers must identify the antecedents of employee turnover. One of the factors contributing to employee turnover is the level of organizational commitment of the employees (Tett \& Meyer, 1993; Griffeth et al., 2000; Du et al., 2006; Baotham et al., 2010; Yucel, 2012). Mowday (1984) proposed that improving the employees' commitment may be one of the measures to prevent employee turnover. Thus, improving the organizational commitment of employees has multifaceted benefits, such as; better organizational performance, resulting in higher productivity.

Singh and Gupta (2015) defined commitment as the attachment, identification, or loyalty to the organization. Organizational commitment is a strong belief in and acceptance of the organization's goals and values, a willingness to exert considerable effort on behalf of the organization, and a strong desire to maintain membership in the organization (Mowday et al., 1982). Aladwan et al. (2013) stated that organizational commitment is a crucial and desirable element in employees' behavior. Because of its importance, a large number of researches have been carried out to understand the antecedents, nature, and consequences of organizational commitment (Chughtai \& Zafar, 2006). Cohen (1993) stated that the issue of organizational commitment continues to get attention both from practitioners and social scientists. An important reason behind such interest in organizational commitment is in its relationship with important organizational outcomes such as turnover intentions (Shore \& Martin, 1989), absenteeism (Farrell \& Peterson, 1984), turnover (Porter et al., 1974), performance (Meyer et al., 1989).

\section{Research Problem}

Different researches were conducted to examine the effect of monthly pay, the number of dependents in the family of the job holder, age, and tenure year on the organizational commitment of the employees. Study of Nazir et al. (2016), Meyer and Smith (2000), Rust et al. (1996) suggested a significant positive correlation between organizational commitment and monthly pay. Similarly, (Siu 2014; Darcy \& McCarthy, 2007) found a significant positive correlation between the organizational commitment and the number of dependent in the family of the job holder. The literature on the relationship between age and organizational commitment revealed a significant positive relationship between the two variables (Hrebiniak \& Alutto, 1972; Koch \& Steers, 1978; Welsh \& LeVan, 1981; Azeem, 2010). The findings of these researches are consistent with the propositions of the side bet theory of Becker (1960). 
Substantial research works are found in the literature revealing a significant positive relationship between tenure year and organizational commitment- suggesting that a longer tenure period resulted in a higher organizational commitment Natarajan and Nagar (2011). However, some of the studies found an inverse relationship between tenure period and organizational commitment Taylor et al. (1996). These studies were conducted in other countries' contexts. A minimal number of researches have been carried out in the Nepalese context to examine the effect pay, number of dependents, age, and tenure period on organizational commitment. Thus, the following problem statements were raised in the Nepalese context.

- Does the monthly salary of teachers significantly affect their organizational commitment?

- What is the relationship between the number of dependents in the family of the teachers and their organizational commitment?

- Does the age of the teachers significantly affect their organizational commitment?

- Does the tenure of the teachers significantly affect their organizational commitment?

\section{Research Objective}

The following are the objectives of this study;

- To examine the effect of monthly payments on the organizational commitment of the teachers working in private schools in Morang, Nepal.

- To investigate if the number of dependents in the family of teachers significantly affects their organizational commitment or not.

- To examine the effect of the age on the level of organizational commitment of the teachers working in private schools of Morang, Nepal.

- To assess the impact of tenure year on the organizational commitment of the teachers working in private schools of Morang, Nepal.

\section{Review of Literature}

Two views of O.C. have dominated the literature (Griffin \& Bateman, 1986). The first view sees commitment as affective or attitudinal and has been called the organizational behavior or psychology approach. This view sees the individual as identifying with the organization and, therefore, committed to maintaining membership to pursue his or her goals (Cohen 1993), and has been termed affective commitment (Meyer \& Allen, 1984) and value commitment (Angle \& Perry, 1981). The second view has its root in the side-bets theory of Becker (1960) asserted (Griffin \& Bateman, 1986). The emphasis of this approach is that previous events have a certain cost; therefore, those costs restraint on a person's options.

Many studies have validated that organizational performance is positively affected by the level of commitment of the employees (Princy \& Rebeka, 2019; Aladwan et al., 2013; Mubashir \& Afifa, 2017). Because highly committed employees will relate themselves with 
the organizational goals and values, have a strong desire to belong to the organization, and are ready to demonstrate a greater affinity in terms of organizational citizenship behavior - a willingness to go over and beyond their required job duties (Mubashir \& Afifa, 2017). Meyer and Allen (1991) stated that organizational commitment is expressed by behavior and attitude that reveal the employees' identification and involvement with their respective organizations, and it has been linked to increased productivity and reduce absenteeism and turnover (Meyer et al., 2002). Employee commitment is the degree to which the employees feel devoted to their organization (Spector, 2000).

Allen and Meyer (1990) developed a conceptual model showing three dimensions of organizational commitment: (1) Affective commitment, (2) normative commitment, and (3) continuance commitment. Allen and Meyer (1990), and Singh and Gupta (2015) asserted that affective commitment implies a choice to remain committed to the organization for some emotional reasons; a continuance commitment is an extent to which an individual feels committed due to their economic reasons (Allen \& Meyer, 1990; Meyer \& Allen, 1984), and finally, a normative commitment is based on perceived attachment due to a feeling of an obligation (Allen \& Meyer, 1990; Singh \& Gupta, 2015).

\section{Theoretical References}

Two major theoretical approaches that have been employed in the literature on organizational commitment are: (a) the exchange approach and (b) the investment approach (Amernic \& Aranya 1983). The exchange theory postulates that the individual's organizational commitment depends on the perceived balance of reward over the input (March \& Simon, 1958; Homans, 1958; Gouldner, 1960). Hrebiniak and Alutto (1972) asserted that the exchange approach emphasizes that the more favorable the exchange from the employees' viewpoint, the greater their commitment to the organization. Other researchers have used exchange theory to analyze an organizational commitment (Bishop et al., 2000). While comparing the exchange relation, the financial reward received by the participant can be an instrumental factor in determining the quality of the exchange relationship. Thus, this study used the exchange theory to examine the effect of monthly payments on total organizational commitment.

Investment Approach as a theoretical model for this study: Salancik (1977) stated that the investment approach centers on the time element. They argued that the longer the employees spend time in an organization, the more the employees want to remain in the organization. Sheldon (1971) described 'investments' as participation in an organization to the extent that possible participation in another organization is decreased. Tenure is an investment of the employee; the longer the tenure, the higher will be a commitment to remain in the organization (Becker, 1960; Grunsky, 1966; Hrebiniak \& Alutto, 1972; Beyer \& Trice, 1978). It is assumed by the investment approach that investments will produce a commitment to the organization (Sheldon, 1971). Similarly, age is another significant predictor of 
organizational commitment of employees (Ritzer \&Trice, 1969; Buchanan, 1974; Hrebiniak \& Alutto, 1972; Stevens, \& et. al 1978; Steers, 1977). Age and tenure are the two essential indicators according to the side-bets approach (Becker, 1960). Side-bets refer to the accumulated investment valued by an individual, which would be lost if the person leaves the organization (Cohen, 1993). Therefore, researchers began to question the importance of tenure and age as determinants of organizational commitment (Cohen \& Lowenberg, 1990). Thus, this study used the investment approach to analyze the effect of age on the organizational commitment of the teachers. Based on these previous literature reviews, this study attempted to test the following hypothesis.

- $\mathrm{H}_{1}$ : There is a significant prediction of total organizational commitment by the monthly payment of the teacher working in Morang, Nepal.

- $\mathrm{H}_{2}$ : There is a significant prediction of total organizational commitment by the numbers of dependents in the family of a teacher working in private schools in Morang, Nepal.

- $\mathrm{H}_{3}$ : There is a significant prediction of total organizational commitment by the age of a teacher working in private schools in Morang, Nepal.

- $\mathrm{H}_{4}$ : There is a significant prediction of total organizational commitment by the tenure year of a teacher working in private schools in Morang, Nepal.

The first section of this article contains a brief introduction of the topic, the objectives, proposed hypothesis, brief literature on the topic, theoretical references, and the limitations of the study. The second section explains the research method and the model to be tested; the third section presents results and discussions of the study, and finally, the conclusion part summarizes the essential findings and their implications.

\section{Methods and Materials}

All the teachers working in private schools of Morang, Nepal, were considered as a target-population of this study. This empirical study was based on cross-sectional data collected from 266 respondents by using a pre-tested, shortened version of the instrument developed by Allen and Meyer (1990), which contained 18 Likert items with five scales each item and 6 Likert items with five scales each item, were added to the instrument to assess job stress of the respondents.

The collected cross-sectional data were analyzed by using the descriptive statistics, Pearson correlation coefficient, and multiple regression models. Therefore, this research used a descriptive and explanatory research design. The mean, standard deviation, maximum, and minimum value were used to describe the characteristics of the metric data. The correlation matrix was used to examine the relationship between a dependent variable and the independent variables, and regression analysis was used to examine the effect of predictor variables on the dependent variable. 
This study used a correlation test between the predictor variables and the Variance Inflation Factor (V.I.F.) to detect the problem of multicollinearity, as suggested by Mansfield and Helms (1982). The correlation matrix helps to identify the multicollinearity problem (Budhathoki et al., 2020). Lind, Marchal, and Wathen (2006) stated that the correlation value between -0.7 to 0.7 , among the regressor variables, does not cause difficulty. Regarding V.I.F., Hair et al. (2010) suggested that V.I.F. with the value of $\leq 4$ does not indicate the problem of multicollinearity. Durbin Watson test was conducted to check the autocorrelation problem in the data. For checking the internal consistency of the data, a reliability test was conducted. Finally, the collected data were analyzed using the Statistical Package for Social Sciences (SPSS), version 25.

This study used the following multiple regression model to test the relationship between the dependent variable and independent variables:

Multiple regression model: $\mathrm{TOC}=\alpha+\beta_{1}(\mathrm{MS})+\beta_{2}(\mathrm{NoD})+\beta_{3}(\mathrm{~A})+\beta_{4}(\mathrm{TY})+\mathrm{u}_{\mathrm{it}}$ Where, $\mathrm{TOC}=$ Total Organizational Commitment, $\mathrm{MP}=$ Monthly Pay, NoD= No. of Dependents in the Family, $A=$ Age, $T Y=$ Tenure Years, and $u_{i t}=$ Error terms

\section{Results and Discussion}

\section{Summary of Descriptive Statistics and Correlation Matrix}

Table 1 presents the demographic profile of the respondents of the study. Out of 266 respondents, 37.6 percent of them were female, and 62.4 percent of respondents were males, implying that the education sector has a higher number of male teachers. Further, a qualification summary of the respondents shows that out of 266 respondents, 42.5 percent of respondents' qualification was bachelors, followed by 41 percent of respondents with masters or above qualification.

\section{Table 1}

Demographic Profiles of Respondents

\begin{tabular}{llcc} 
Demographic Profiles of Respondents & & $(N=266)$ \\
\hline Demographic Variables & Groups & $\mathrm{N}$ & Percent \\
\hline \multirow{2}{*}{ Gender } & Female & 100 & 37.6 \\
& Male & 166 & 62.4 \\
\multirow{3}{*}{ Qualification } & Certificate of Below & 44 & 16.5 \\
& Bachelors & 113 & 42.5 \\
\multirow{2}{*}{ Marital Status } & Masters or Above & 109 & 41 \\
& Single & 82 & 30.8 \\
& Married & 184 & 69.2 \\
\hline
\end{tabular}

Note. Survey 2020. 
The percentage of respondents with a 'certificate or below' was least, i.e., 16.5 percent, indicating that around 82 percent of the teachers working in private schools have a minimum of bachelor's level qualification. Similarly, 69.2 percent of the teachers were married, and the rest, 30.8 percent of respondents were single.

Table 2 exhibits a scale summary of the instrument used in the study. The scale summary was prepared after conducting a reliability test of the instrument. To measure the construct organizational commitment, 18 Likert items with five scales to each item were used. Similarly, for measuring the variable job stress, 6 Likert items with five scales to each item were used. The Cronbach's Alpha value of the organizational commitment is $=0.801$, and for the job stress $=0.773$. The Cronbach's alpha values of both constructs were robust. A generally accepted rule is that Alpha value in between 0.6-0.7 indicates an acceptable level of reliability, and 0.8 or greater a very good level (Ursachi et al., 2013). However, Cronbach's alpha values higher than 0.95 are not necessarily good since they might be an indication of redundancy (Hulin et al., 2001).

Table 2

Scale Summary

\begin{tabular}{lcccccc}
\hline Scale & $\begin{array}{c}\text { Retained } \\
\text { Items }\end{array}$ & $\begin{array}{c}\text { Cronbach } \\
\text { Alpha }\end{array}$ & Min & Max & Mean & $\begin{array}{c}\text { Standard } \\
\text { Deviation }\end{array}$ \\
\hline Total O.C. & 18 & 0.801 & 7 & 23 & 11.714 & 3.614 \\
Total Job Stress & 6 & 0.773 & 28 & 62 & 46.410 & 9.050 \\
\hline
\end{tabular}

Note. Reliability test.

Table 3 reports a summary of the descriptive statistics of four predictor variables: Age, Monthly Pay, No. of dependents in the family, and Tenure Year; one response variables- Total Organizational Commitment, used in the study. The results suggest that the average of the respondents was approximately 27 years. Approximately two family members were dependent on the employees under this investigation. Similarly, the average monthly pay of the teachers was approximately Nrs. 15800. The average tenure year of the respondent was nearly three years. The result found average organizational commitment (to measure the organizational commitment, 18 items with a maximum of 5 scales indicating to agree strongly were used. Thus, the maximum possible score for organizational commitment is $=90(18 \times 5)$. The midvalue of the maximum score is $=45(90 / 2)$. This point is arbitrarily considered as a minimum point of reference for organizational commitment).

From table 3, it is evident that the organizational commitment of the employees under this study was moderate. The values of the standard deviation of each variable measure the average distance of the data point from the mean value. In this study, since each of the 
following variables presented in table 3 is heterogeneous, the values of standard deviations do not have serious implications.

Table 3

Descriptive Statistics of Response and Predictor Variables

\begin{tabular}{lccccc}
\hline Variables & N & Minimum & Maximum & Mean & $\begin{array}{c}\text { Std. } \\
\text { Deviation }\end{array}$ \\
\hline Age (A) & 266 & 19 & 36 & 27.0414 & 3.2798 \\
No of dependents in the family & & & & & \\
(NoD) & 266 & 1 & 4 & 2.3308 & 0.6469 \\
Monthly Pay (M.P. in Nrs.) & 266 & 8000 & 22000 & 15805.8271 & 4033.29 \\
Tenure Year (T.Y.) & 266 & 1 & 9 & 3.1842 & 1.5296 \\
Total Organizational Commitment & & & & & \\
(T.O.C.) & 266 & 28 & 62 & 46.4098 & 9.0496 \\
\hline
\end{tabular}

Note. Survey 2020.

Table 4 presents Table 2 presents the correlation matrix of response and predictor variables. The results suggest a significant positive correlation at a $1 \%$ level between the dependent variable (organizational commitment) and all the predictor variables (tenure year, monthly pay, age, and the numbers of dependents in the family). Similarly, the correlations between all the predictor variables are also significantly positive. In the meantime, all the correlation coefficients, among the predictor variables, are less than 0.7 . Therefore, there is no evidence of multicollinearity problem among predictor variables.

A significant positive correlation between age, tenure, and organizational commitment is consistent with the developmental model of Super (1957), which argues that older, more tenured employees are more committed to their organizations than the younger and less experienced employees. Even the finding of Azeem (2010) supports this result, that age is a significant predictor of organizational commitment. Similarly, the significant positive Correlation between organizational commitment and monthly pay is consistent with the findings of other researchers. Satisfaction with extrinsic reward and organizational commitment are significantly related factors (Nazir et al., 2016; Meyer and Smith, 2000; Rust et al., 1996). They argued that extrinsic benefits are a crucial component, which is used by human resource practitioners to keep their employees committed and satisfied. Extrinsic benefits refer to the package of financial rewards offered to the employees by the organization (Newman \& Sheikh, 2012). A significant positive correlation between organizational commitment and the number of dependents, this result is consistent with the findings of other researchers (Siu et. al., 2014; Darcy \& McCarthy, 2007). 
Table 4

Correlation Matrix of Response and Predictor Variables

\begin{tabular}{lccccc}
\hline \multicolumn{1}{c}{ Variables } & TN & MP & A & NoD & T.O.C. \\
\hline TN & 1 & & & & \\
MP & $.692^{* *}$ & 1 & & & \\
& 0.000 & & & & \\
A & $.425^{* *}$ & $.304^{* *}$ & 1 & & \\
& 0.000 & 0.000 & & & \\
NoD & 0.095 & $.214^{* *}$ & 0.074 & & \\
& 0.124 & 0.000 & 0.232 & & \\
TOC & $.550^{* *}$ & $.857^{* *}$ & $.332^{* *}$ & $.347^{* *}$ & 1 \\
& 0.000 & 0.000 & 0.000 & 0.000 & \\
\hline
\end{tabular}

Note. ** Correlation is significant at the 0.01 level (2-tailed).

\section{Regression Results}

Tables 5 shows the results of regression analysis of the dependent variable (organizational commitment) and predictor variables (monthly pay, the number of dependents in the family, age, and tenure years). The multiple regression analysis results reveal that total organizational commitment is affected by monthly pay, the number of dependents in the family, age, and the tenure year of the employees. The value of $\mathrm{R}^{2}(.774)$ reveals that the overall explanatory power of the regression model was acceptable. R-square value of 0.6 is satisfactory (Hair et al. (2013). The value of $\mathrm{R}^{2}$ (.774) indicates that the variation in the independent variables explained 77.4 percent of the variation in the total organizational commitment. The $\mathrm{p}$ value of F-statistics indicates that the proposed regression model is a good fit. Likewise, the variance inflation factor (V.I.F.) of all the variables is less than 3. The value of V.I.F. less than 5 implies the non-presence of a multicollinearity problem (Tiko et. al., 2015). In Table 5, the regression coefficient of the monthly pay $\left(\beta_{1}=.002, \mathrm{p}=.000\right)$ indicates that a higher monthly pay resulted in the higher Total Organizational Commitment (T.O.C.) of the teachers working in private schools in Morang. The result of this study is in line with the findings of (Taba, 2018; Hrebiniak \& Alutto, 1972; Koch \& Steers, 1978; Welsh \& LeVan, 1981; Azeem, 2010; Nazir et al., 2016; Meyer \& Smith, 2000; Rust et al., 1996).

The regression coefficient of the (NoD)- number of the dependents in the family $\left(\beta_{2}=\right.$ $2.306, \mathrm{p}=0.000$ ) indicates that as the number of the dependents in the family of the teachers' increases, the total organizational commitment of the employees will also increase. This result 
is consistent with the findings of Siu (2014). The study of Siu (2014) revealed that employees with more dependents have a higher organizational commitment compared to employees without dependents. When people marry and children are born, work-family conflict increases Darcy and McCarthy (2007). When an employee has many dependents in the family, the responsibility or family obligation also increases. This may be a possible reason behind a significant positive relationship between the number of dependents of an employee and their organizational commitment.

The regression coefficient of (T.Y.) - tenure year $\left(\beta_{3}=-.643, \mathrm{p}=0.0012\right)$ indicates that longer tenure years resulted in the lower organizational commitment. Inconsistent with the propositions of the Side bet theory of Becker (1960). Behind such a result, in this study, there may be several reasons; for instance, longer-tenured employees might not have promotional opportunities; the repetitive nature of the task might have caused monotony. However, further researches are required to explore the causes of this research.

The regression coefficient of (A) - age $\left(\beta_{4}=.283, \mathrm{p}=0.002\right)$ indicates that a higher age resulted in a higher total organizational commitment. The result of the positive relationship between age and organizational commitment is in line with the findings of (Hrebiniak \& Alutto, 1972; Koch \& Steers, 1978; Welsh \& LeVan, 1981). Their findings revealed a significant positive relationship between age and organizational commitment. However, this result is in contrast to the findings of Rubin and Brody (2005). Their findings indicated that the commitment of the older employee was negatively affected by time demands and schedule control. They attribute cohort differences to the shift in the social contract experienced by older workers.

The result of a significant negative relationship between organizational commitment and tenure is in contrast with the findings of Natarajan \& Nagar (2011) and Taylor et al. (1996). Similarly, other researchers found a monotonic increase in the organizational commitment across different career stages based on the tenure of the employees (Allen \& Meyer, 1993; Cohen, 1993), and some have found a U shaped results (Morrow \& McElroy, 1987; and Reilly \& Orsak, 1991). A significant positive relation between tenure year, age, and organizational commitment may be because as the tenure period increases, the workers create a social life in the organization, the collaboration with their coworkers becomes high, familiarity with the organizational culture becomes clearer, and these factors work as a buffer to reduce work stress (Olatunji \& Mokuolu, 2013). Longer job tenure gives workers the on-the-job experience that produces autonomy or the positive relationships with supervisors that produces social support Brimeyer et al. (2010). 
Table 5

Multiple Regression Equation of T.O.C. on all Predictor Variables

\begin{tabular}{lcccc}
\hline Variables & $\begin{array}{c}\text { Unstandardised Beta } \\
\text { Coefficient }\end{array}$ & $\begin{array}{c}t- \\
\text { statistics }\end{array}$ & $\begin{array}{c}P \text { - } \\
\text { value }\end{array}$ & V.I.F. \\
\hline Intercept & 4.723 & 1.882 & 0.061 & \\
Monthly Pay (MP) & $0.002^{*}$ & 20.762 & 0.000 & 2.004 \\
No of dependents in the & & & & \\
family (NoD) & $2.306^{*}$ & 5.447 & 0.000 & 1.055 \\
Age (A) & $0.283^{*}$ & 3.151 & 0.002 & 1.222 \\
Tenure Year (T.Y.) & $\left(-0.643^{* *}\right)$ & -2.522 & 0.012 & 2.141 \\
$F$-statistics & $222.91^{*}$ & $R^{2}$ & 0.774 & \\
$P$-value & 0.000 & & & \\
\hline
\end{tabular}

Note. $*$ Statistical significance at the $1 \%$ level, $* *$ Statistical significance at the $5 \%$ level.

\section{Conclusion, Implication, and Limitations of the Study}

The purpose of this study was to examine the effect of monthly pay, numbers of dependents in the family of the teachers, age, and tenure period on the organizational commitment of the teachers working in the private schools of Morang, Nepal. The literature shows a paucity of studies conducted in the Nepalese context to assess the impact of the independent variables on the dependent variables used in this study. The other empirical studies conducted in other settings found the mixed results regarding the effect of the predictor variables used in this study on the organizational commitment of employees from different sectors. Therefore, this study was conducted to examine the impact of monthly payments, the number of dependents in the family, age, and tenure of the teachers on their organizational commitment. This study used one ordinary least squares regression models to explain the cause-and-effect relationship between a dependent (T.O.C.) and independent variables (M.P., NoD, A. \& T.Y.). The regression model was statistically significant $(\mathrm{F}=222.91,<.01)$ suggesting that the regression model was best fitted. The regression equation revealed that higher monthly payment, an increase in the number of dependents in the family of the teachers, and age had a significant positive effect on the total organizational commitment of the teachers working in private schools in Morang. However, tenure years had a significant negative relationship with the total organizational commitment of the teachers working in private schools in Morang. This finding can be beneficial to the founders of the private schools to take effective measures to formulate an effective human resource policy for enhancing the organizational commitment of their teachers and improve the teachers' effectiveness in 
performing their jobs. Organizational commitment is important because high levels of commitment lead to several favorable organizational outcomes (Karanja, 2017; Irefin, 2014).

This study covered only four independent variables; such as monthly pay, the number of dependents in the family, age, and tenure year - to show the impact organizational commitment of the teachers of private schools or Morang; therefore, further research needs to be done by including other more relevant variables in the Nepalese context.

\section{Reference}

Aladwan, K., Bhanugopan, B., \& Fish, A. (2013). To what extent the Arab workers committed to their organizations? International Journal of Commerce and Management, 23(4), 306326.

Allen, N. J., \& Meyer, J. P. (1993). Organizational commitment: Evidence of career stage effects?. Journal of Business Research, 26, 49-61.

Amernic, J. H., \& Aranya, N. (1983). Organizational commitment: Testing two theories. Industrial Relations, 38(2), 319-343.

Angle, H. L., \& Perry, J. L. (1981). Organizational commitment and organizational effectiveness: An empirical assessment. Administrative Science Quarterly, 26, 1-14.

Azeem, S. M. (2010). Job satisfaction and organizational commitment among employees in the sultanate of Oman. Psychology, 1, 295-299. https://doi.org/10.4236/psych.2010.14038

Baotham, S., Hongkhuntod, W., \& Rattanajun, S. (2010). The effects of job satisfaction and organizational commitment on voluntary turnover intentions of Thai employees in the New University. Review of Business Research, 10(1), 73-82.

Becker, H. S. (1960). Notes on the Concept of Commitment. American Journal of Sociology, 66, 32-40.

Bishop, J.W., Scott, K. D., \& Burroughs, S.M. (2000). Support, commitment, and employee outcomes in a team environment. Journal of Management, 26, 1113-1132.

Brimeyer, T. M., Perrucci, R., \& Wadsworth, S. M. (2010). Age, tenure, resources for control, and organizational commitment. Social Science Quarterly, 91(2) 511-530.

Buchanan, B. (1974). Building organizational commitment: The socialization of managers in work organizations. Administrative Science Quarterly, 19, 533-546.

Budhathoki, P. B., Rai, C. K., Lamichhane, K. P., Bhattarai, G., \& Rai, A. (2020). The impact of liquidity, leverage, and total size on banks' profitability: Evidence from Nepalese Commercial Banks. Journal of Economics and Business, 3(2), 545-555. 
Chughtai, A. A., \& Zafar, S. (2006). Antecedents and consequences of organizational commitment among Pakistani University Teachers. Applied H.R.M. Research, 11(1), 3964.

Cohen, A. (1993). Age and tenure in relation to organizational commitment: A Meta-Analysis. Basic and Applied Social Psychology 14(2), 143-159.

Cohen, A., \& Lowenberg, G. (1990). A reexamination of the side-bet theory as applied to organizational commitment: A meta-analysis. Human Relations, 43, 1015-1050.

Darcy, C. \& McCarthy, A. (2007). Work-Family conflict: An exploration of the differential effects of a dependent child's age on working parents. Journal of European Industrial Training, 31(7), 530-549. https://doi.org/10.1108/03090590710820042

Du, J.J., Zhou, J., Lui, C.E. \& Picken, D. (2006). Exploring the turnover intention of construction managers in China. Journal of Construction Research, 7(1-2), 191-205.

Farrell, D., \& Petersen, J. C. (1984). Commitment, absenteeism, and turnover of new employees: A longitudinal study. Human Relations, 37, 681-692.

Gouldner \& Alvin, W. (1960). The norm of reciprocity: A preliminary statement. American Sociological Review, 25, 161-179.

Griffeth, R.W., Hom, P.W., \& Gaertner, S. (2000). Meta-analyses of antecedents and correlates of employee turnover: Update, moderator tests, and research implications for the next millennium. Journal of Management, 26(3), 463-488.

Griffin. R. W., \& Bateman, T. S. (1986). Job satisfaction and organizational commitment. In C. L. Cooper \& I. Robertson (Eds.), International Review of Industrial and Organizational Psychology, 157-188). New York: Wiley.

Grunsky, O. (1966). Career mobility and organizational commitment. Administrative Science Quarterly, 110, 448-503.

Hair, J. F., Ringle, C. M., \& Sarstedt, M. (2013). Editorial - Partial least squares structural equation modelling: Rigorous applications, better results, and higher acceptance. Long Range Planning, 46(1-2), 1-12.

Hair, J., Black, W. C., Babin, B. J., \& Anderson, R. E. (2010). Multivariate data analysis (7th ed.). Upper Saddle River, New Jersey.

Hassan, R. (2014). Factors influencing turnover intention among technical employees in information technology organization: A case of Xyz (M) Sdn. Bhd. International Journal of Arts and Commerce, 120-137.

Homans. (1958). Social behaviour as exchange. American Journal of Sociology, 63, 597-606. 
Hrebiniak, L. G. \& Alutto, J. A. (1972). Personal and role-related factors in the development of organizational commitment. Administrative Science Quarterly, 17, 563-573.

Hulin, C., Netemeyer, R., \& Cudeck, R. (2001). Can a reliability coefficient be too high? Journal of Consumer Psychology, 10(1), 55-58.

Idris, A. (2014). Flexible working as an employee retention strategy in developing countries: Malaysian bank managers speak. Journal of Management Research, 14(2), 71-86.

Irefin, P. \& Mechanic, M. A. (2014). Effect of employee commitment on organizational performance in Coca Cola Nigeria Limited Maiduguri, Borno State. IOSR Journal of Humanities And Social Science (IOSR-JHSS), 19(3), 33-41.

Karanja, N. E., Karanja, G. W., Wagoki, A. J. (2017). Influence of pay disparity among employees on organizational commitment in the county government of Nakuru, Kenya. IOSR Journal of Humanities And Social Science (IOSR-JHSS, 22(10), 76-86.

Koch, J. L., \& Steers, R. M. (1978). Job attachment, satisfaction, and turnover among public sector employees. Journal of Vocational Behavior 12, 119-128.

Lind, D. A., Marchal, W. G., \& Wathen, S. A. (2006). Basic statistics for business and statistics. New York, NY: McGraw Hill.

Mansfield, E. R., \& Helms, B. P. (1982). Detecting Multicollinearity. The American Statistician, 36(3), 158-160. https://doi.org/10.2307/2683167

March, J. G. \& Simon, H. A. (1958). Organizations, John Wiley \& Sons, Inc.,

Meyer, J. P., \& Allen, J. N. (1984). Testing the side-bet theory of organizational commitment: some methodological considerations. Journal of Applied Psychology. 69, 372-378.

Meyer, J. P., \& Allen, N. (1997). Commitment in the workplace: Theory, research, and application. London, England: Sage.

Meyer, J. P., Stanley, D., Herscovitch, L. \& Topolnytsky, L. (2002). Affective, continuance, and normative commitment to the organization: a meta-analysis of antecedents, correlates, and consequences. Journal of Vocational Behavior. 61, 20-52. https://doi.org/10.1006/jvbe.2001.1842.

Meyer, J.P. \& Allen, N.J. \& Smith, C.A. (1993). Commitment to organizations and occupations: extension and test of a three-component conceptualization. Journal of Applied Psychology,78 (4), 538-551.

Meyer, J.P. \& Allen, N.J. (1991). A three-component conceptualization of organizational commitment. Human Resource Management Review, 1(1), 61-89. https://doi.org/10.1016/1053-4822(91)90011-Z. 
Meyer, J.P. \& Smith, C.A. (2000). H.R.M. practices and organizational commitment: A test of a mediation model. Canadian Journal of Administrative Sciences, 17(4), 319-331.

Morrow, P. C., \& McElroy, J. C. (1987). Work commitment and job satisfaction over three career stages. Journal of Vocational Behavior, 30(3), 330-346. https://doi.org/10.1016/0001-8791(87)90009-1

Mowday, R. (1984). Strategies for adapting to high rates of employee turnover. Human Resource Management, 23(4), 365-380. https://doi.org/10.1002/hrm.3930230404.

Mowday, R. T., Porter, L. W., \& Steers, R. M. (1982). Employee-organization linkages: The Psychology of commitment, absenteeism, and turnover. New York: Academic Press.

Mowday, R. T., Steers, R. M., \& Porter, L. W. (1979). The measurement of organizational commitment. Journal of Vocational Behavior, 14(2), 224-247.

Mubashir, B. \& Afifa, I. (2017). Measurement of organizational commitment and factors influencing the level of commitment of employees-an empirical investigation of higher education system. International Journal of Management \& Business Studies, 7(1), 14-18.

Natarajan N. K. \& Nagar D. (2011). Effects of service tenure and nature of occupation on organizational commitment and job satisfaction. Journal of Management Research, 11(1), 59-64

Nazir, S., Shafi, A., Qun, W., Nazir, N., \& Tran, Q. D. (2016). Influence of organizational rewards on organizational commitment and turnover intentions. Employee Relations, 38(4), 596-619. https://doi.org/10.1108/ER-12-2014-0150

Newman, A., \& Sheikh, A. (2012). Organizational commitment in Chinese small-and-mediumsized enterprises: The role of extrinsic, intrinsic, and social rewards. The International Journal of Human Resource Management, 23(2), 349-367.

Olatunji, S. O., \& Mokuolu, B. O. (2013). Effect of tenure of service on job stress and nursephysician collaboration among nurses and doctors. IOSR Journal of Nursing and Health Science (IOSR-JNHS), 2(1), 1-4.

Porter, L. W., Steers, R. M., Mowday, R. T., \& Boulian, P. V. (1974). Organizational commitment, job satisfaction, and turnover among Psychiatric Technicians. Journal of Applied Psychology, 59, 603-609.

Princy, K. \& Rebeka, E. (2019) Employee commitment on organizational performance. International Journal of Recent Technology and Engineering (IJRTE), 8(3), 891-895.

Reilly, N. P. \& Orsak, C. L. (1991). A career stage analysis of career and organizational commitment in Nursing. Journal of Vocational Behavior, 39(3), 311-330. 
Ritzer, G. \& Trice, H. (1969). An empirical study of Howard Becker's Side Bet Theory. Social Forces, 47, 475-479.

Rubin, B. A. \& Brody, C. J. (2005). Contradictions of commitment in the new economy: insecurity, time, and technology. Social Science Research, 34, 843-61.

Rust, R.T., Stewart, G.L., Miller, H., \& Pielack, D. (1996). The satisfaction and retention of frontline employees: A customer satisfaction measurement approach. International Journal of Service Industry Management, 7(5), 62-80.

Salancik, G.R. \& Staw, B. M. (1977). Commitment and control of organizational behavior and belief. New Directions in Organizational Behavior, 111, 1-54.

Sheldon, M. E. (1971). Investments and Involvements as Mechanisms Producing Commitment to the Organization. Administrative Science Quarterly, 16, 143-150.

Shore, L. M., \& Martin, H. J. (1989). Job satisfaction and organizational commitment in relation to work performance and turnover intentions. Human Relations, 42, 625-638.

Singh, A., \& Gupta, B. (2015). Job involvement, organizational commitment, professional commitment, and team commitment. Benchmarking: An International Journal, 22(6), 1192-1211. https://doi.org/10.1108/BIJ-01-2014-0007

Siu, O. L., Cooper, C. L., \& Phillips, D. R. (2014). intervention studies on enhancing work well-being, reducing burnout, and improving recovery experiences among Hong Kong health care workers and teachers. International Journal of Stress Management, 21(1), 69-84. https://doi.org/10.1037/a0033291

Spector, P. E. (2000). Industrial and organizational psychology: Research and practice. New York: John Wiley and Sons.

Steers, R. M. (1977). Antecedents and outcomes of organizational commitment. Administrative Science Quarterly, 22, 46-56.

Stevens, J. M., Beyer, J. M. \& Trice, H. M. (1978). Assessing personal, role, and organizational predictors of managerial commitment. Academy of Management Journal, 21, 380-396.

Suliman, A., \& Iles, P. (2000). Is Continuance Commitment Beneficial to Organizations? Commitment-Performance Relationship: A New Look. Journal of Managerial Psychology, 15(5), 407-422.

Super, D. E. (1957). The psychology of careers: An introduction to vocational development. New York: Harper. 
Taba, M. I. (2018). Mediating effect of work performance and organizational commitment in the relationship between the reward system and employees' work satisfaction. Journal of Management Development, 37(1), 65-75. https://doi.org/10.1108/JMD-11-2016-0256

Taylor, M. S., Audia, G., \& Gupta, A. K. (1996). The effect of lengthening job tenure on managers' organizational commitment and turnover. Organization Science, 7(6), 632648. https://doi.org/10.1287/orsc.7.6.632

Tett, R.P. \& Meyer, J.P. (1993). Job satisfaction, organizational commitment, turnover intention, and turnover: path analyses based on meta-analytic findings. Personnel Psychology, 46(2), 259-293. https://doi.org/10.1111/j.1744-6570.1993.tb00874.x.

Tiko, J., Skvarciany, V., \& Jureviciene, D. (2015). Drivers of bank profitability: Case of Latvia and Lithuania. Intellectual Economics, 9, 120-129. http://dx.doi.org/10.1016/j.intele.2016.02.003

Tuna, M., Ghazzawi, I., Tuna, A., \& Catir, O. (2016). Perceived external prestige and organizational deviance: The case of Turkey's Hospitality Industry. International Journal of Contemporary Hospitality Management (IJCHM), 28(2), 366- 396.

Ursachi, G., Horodnic, I. A., \& Zait, A. (2013). How reliable are measurement scales? External factors with indirect Influence on reliability estimators. Procedia Economics and Finance, 20 (2015), $679-686$

Welsh, H. P., \& LeVan, H. (1981). Interrelationship between organizational commitment and job characteristics, job satisfaction, professional behavior, and organizational climate. Human Relations, 34, 1079-1089.

Wu, X. \& Polsaram, P. (2011). Factors influencing employee turnover intention: The case of retail industry in Bangkok. Thailand. Available Online: https://pdfs.semanticscholar.org/a715/9813890a42a05410b1a84552f5bde9c8fdf2.pdf? $\mathrm{ga}=2.102150216 .833061833 .1586581209-1783174523.1569027091$ (Date Accessed: $14 / 8 / 2020)$

Yucel, I. (2012). Examining the relationship among job satisfaction, organizational commitment, and turnover intention: An empirical study. International Journal of Business Management, 7(20), 44-57. https://doi.org/10.5539/ijbm.v7n20p44. 